\title{
Financial Distress Prediction: The Ownership Structure and Managerial Agency Cost
}

\author{
MAYA INDRIASTUTI * \\ INDRI KARTIKA \\ NAILA NAJIHAH \\ Universitas Islam Sultan Agung
}

\begin{abstract}
This research aimed to predict financial distress through ownership structure and managerial agency cost. The ownership structure was tested by managerial ownership and institutional ownership. Meanwhile, the managerial agency cost was tested by the administrative cost ratio. The population of this research was all companies listed in the Indonesia Sharia Stock Index year 2016-2018 by using the purposive sampling technique. Based on the criteria that have been determined, the total samples were 129 companies. The analysis of the data in this research used logistic regression analysis. The results showed that institutional ownership has a negative effect on financial distress. Despite this, the managerial ownership and managerial agency cost does not affect the financial distress.
\end{abstract}

Keywords: Ownership Structure, Managerial Agency Cost, Financial Distress, Indonesia Sharia Stock Index, Logistic Regression Analysis

\begin{abstract}
Abstrak-Penelitian ini bertujuan untuk memprediksi kesulitan keuangan melalui struktur kepemilikan dan biaya keagenan manajerial. Struktur kepemilikan diuji dengan kepemilikan manajerial dan kepemilikan institusional. Sedangkan biaya agensi manajerial diuji dengan rasio biaya administrasi. Populasi dalam penelitian ini adalah seluruh perusahaan yang terdaftar di Indeks Saham Syariah Indonesia tahun 20162018 dengan menggunakan teknik purposive sampling. Berdasarkan kriteria yang telah ditentukan maka jumlah sampel dalam penelitian ini sebanyak 129 perusahaan. Analisis data dalam penelitian ini menggunakan analisis regresi logistik. Hasil penelitian menunjukkan bahwa kepemilikan institusional berpengaruh negatif terhadap kesulitan keuangan. Sedangkan kepemilikan manajerial dan biaya agensi manajerial tidak berpengaruh terhadap kesulitan keuangan.
\end{abstract}

Kata Kunci: Struktur Kepemilikan, Biaya Agensi Manajerial, Kesulitan Keuangan, Indeks Saham Syariah Indonesia, Analisis Regresi Logistik

\footnotetext{
* Corresponding author: maya@ unissula.ac.id
} 


\section{Introduction}

Financial distress is a stage where the financial conditions experience a decrease. It occurs in companies before bankruptcy or liquidation (Platt and Platt, 2002; Wruck, 1990). A company is categorized as experiencing financial distress if the company shows a negative number on the operating income, net income, and equity book value also the company that makes a merge (Al-Khatib et al., 2012). Another phenomenon of financial distress is that companies tend to experience liquidity difficulties, as indicated by the company's failure to fulfill its obligations to creditors (Hanifah \& Purwanto, 2013). Brigham \& Daves (2003) stated that financial distress occurs over several errors, such as improper decision making, interconnected weaknesses that can affect directly or indirectly management, and the lack of efforts to control the company's financial condition. Thus, the implementation is not as needed. This situation gives the conclusion that there is no guarantee that large companies can avoid this problem. Financial distress is related to the company's financial condition, where every company will surely deal with finance to achieve profit targets and company sustainability.

Companies that have experienced financial distress need to do predictive analysis and early detection before going bankrupt (Azwar, 2015). Agus (2011) added that this analysis is also needed by interested parties such as investors, policymakers, auditors and competitor companies, and the general public. Specifically for investors, the analysis results will be used to choose the attitude towards the securities owned by the company where it will invest. Bhunia et al. (2011); Haddad et al. (2011) stated that financial distress in companies could cause problems that can reduce management efficiency. Therefore, we need a strong corporate governance structure and managerial agency costs in the company.

Elloumi et al. (2001), Li et al. (2008), Parulian (2007) stated that corporate governance affects financial distress. Ariean (2012) stated that financial distress arises because of the weak supervision from shareholders, the board of commissioners, and bank creditors. Otherwise, the better corporate governance implementation in a company, the lower probability of financial distress will be in a company. This notion is in line with the opinion of Porter (1999); Classens (1999), the reason for a company's 
success or failure is caused by the strategy adopted by the company. These studies mean that the success of a majority company is determined by the strategic and managerial characteristics of the company, including the strategy of implementing a corporate governance system (Sutedi, 2011). The implementation of good corporate governance will foster a harmonious relationship between the board of directors and company management (Arief, 2009).

Indriastuti \& Ifada (2011); Indriastuti (2012); Miglani et al., (2014); Muranda (2006) stated that corporate governance is needed to ensure that the strategic direction and management of the company do not shift from existing plans and also to reduce the practice of fraud from the company's internal environment. However, managing a company can cause a conflict of interest between shareholders and agents. Conflicts of interest due to the possibility that agents do not always act following principals' interests trigger management agency costs (Jensen and Meckling, 1976). Li et al. (2008) suggested that management agency costs affect financial distress. The distress is because administrative costs incurred as managerial agency costs can adversely affect the company's financial condition. Ayuningtias. (2013) added that managerial agency cost influences financial distress.

Based on the description above, this study analyzes and empirically tests the factors that can predict financial distress in Indonesia's Islamic stock index companies. The Indonesia Islamic stock index, which was launched on May 12, 2011, is a composite index of Islamic stocks listed on the Indonesia Stock Exchange (www.idx.co.id). The contribution of this research theoretically adds to the literature concerning corporate governance, especially ownership structure and managerial agency costs, so it enriches references for further research. Practically, this research contributes to companies that are members of the Indonesia Islamic stock index as a guide in implementing good corporate governance to manage managerial agency costs to minimize financial distress. For investors and potential investors, this research can be used as a guide in making investment decisions. Investors and potential investors can choose companies that are not experiencing financial distress so that their investments can be safe. 


\section{Theoretical Framework and Hypothesis Development}

\subsection{Agency Theory}

Agency theory is the basis used to understand corporate governance and financial distress. Agency theory is concerned with the contractual relationship among members of the company to avoid inappropriate relationships. It needs a concept of good corporate governance which aims to make the company healthier. The application of corporate governance (through ownership structure) is based on agency theory, which is a theory that can explain the relationship between management and owners. Management as an agent is morally responsible for optimizing the owners' profits (principals) and, in return, will receive compensation under the agreement (Jensen \& Meckling, 1976).

Shareholders, as principals, delegate managers who are representatives or agents of shareholders to make a decision. The problem that arises from this corporate ownership system is that agents do not always make decisions to fulfill the principal's best interests. One of the main assumptions of agency theory is the different principal and agent goals, resulting in agency costs. It is because corporate managers tend to pursue personal goals. It can lead to a tendency for managers to focus on projects and company investments that generate high returns in the short term rather than maximizing shareholder's wealth through investing in projects that are profitable for a long time (Jensen \& Meckling, 1976).

According to the description above, in corporate governance, through the ownership structure based on agency theory, each individual maximizes their utility. If both parties maximize each other's utility, then there is reason to believe that the agent or manager does not always act in the principal's best interests (Jensen \& Meckling, 1976). The principal can limit the separation of his interests by creating appropriate incentives for the agent. It will lead to monitoring costs that are used to restrict the activities of deviant agents because agents often behave as if they are maximizing the welfare of the principal; in fact, they are not. 


\subsection{Ownership Structure}

\subsubsection{Managerial Ownership}

Agency conflict is caused by the separation of ownership and control in the company. The more concentrated the company's ownership in one person, the stronger the control, reducing agency costs. The more significant the proportion of management ownership in a company, the management will try harder to meet the interests of shareholders who are also themselves. The understanding of company ownership is crucial because it relates to the company's operational control. The management's share ownership percentage tends to influence management's bad actions, which impact financial distress. Managerial ownership can reduce the incentives of self-serving managers through intense levels of supervision (Indriastuti, 2012). In conclusion, managerial ownership is an operational control related to accounting and agency cost management determined based on the company's work motivation.

\subsubsection{Institutional Ownership}

Institutional ownership is the proportion of shares owned by institutions (nonindividual ownership) to the total outstanding shares (Abdel, 2003; Cox et al., 2004; Graves \& Waddock, 1993; Johnson \& Greening 1999). Tonello \& Rabimov (2010) added that the amount of ownership that institutional investors can own is more than 50 percent of the company's outstanding equity. Accordingly, each institutional investor can hold large positions in many publicly traded companies.

Institutional ownership means that (1) temporary owners focus on current earnings so that managers are forced to increase profits, and (2) sophistication occurs for monitoring more effectively and are not easily deceived or believed by manipulation by managers. Institutional ownership can control management through an effective monitoring process to reduce management's bad actions that impact financial distress. Through the mechanism of institutional ownership, the effectiveness of the management of company resources by management can be known from the information generated through the market reaction to earnings announcements. It can be concluded that institutional ownership is a company share owned by an institutional company that can control management through a supervisory process. 


\subsection{Managerial Agency Cost}

Agency costs are costs borne by the owner shareholder (principal) when company management (agent) buys another company to expand its power or spends money on preferred projects instead of maximizing firm value (Jensen \& Meckling, 1976). In managing the company's operations, there are costs such as managerial salaries, executive expenses, travel expenses, entertainment expenses, expenses for conferences, welfare payments, and other charges, all covered in the company's administrative expenses. Administrative costs are considered a measure for the consumption of additional income and managerial discretion in allocating company resources. Thus, managerial agency costs are indispensable for managerial control in allocating company resources.

\subsection{Financial Distress}

Financial distress in a company occurs when the company cannot meet its payment schedule or when cash flow projections indicate that it will soon be unable to meet its obligations (Bringham and Daves, 2014). (Bringham and Daves, 2014) added that there are five financial difficulties, including 1). Economic failure, where the company cannot cover the total costs, including the capital cost, 2). Business failure occurs when the business stops operations with the result of losses to creditors, 3). Technical insolvency; the inability to meet current obligations when they fall due, indicating a temporary liquidity shortage, 4). Insolvency in bankruptcy, as illustrated by the book value of debt that exceeds the market value of assets, and 5). Legal bankruptcy occurs when a lawsuit has been officially filed under the law.

In addition, financial distress that occurred in the company was caused by: increase in operating costs, excessive expansion, technology lag, competitive conditions, economic conditions, weakness of company management, and a decrease in industrial trading activities.

\subsubsection{Financial Distress Prediction}

A warning system model to anticipate financial distress needs to be developed because this model can identify and even improve conditions before they reach a crisis 
or bankruptcy condition. (Platt \& Plat, 2002) defined financial distress as the stage of decline in financial conditions before bankruptcy or liquidation occurs.

\subsection{Managerial Ownership and Financial Distress}

Managerial ownership is assumed to be able to reduce agency problems in a company. If the problems occur continuously, it can cause financial distress in the company. The situation is caused by managerial ownership; the decision-making related to the company will be carried out with full responsibility because it follows the interests of shareholders in this case, including the interests of management as one of the components of the company owner (Emrinaldi, 2007). Ownership by management will also increase management supervision of the company itself (Triwahyuningtias \& Muharam, 2012). Agency theory suggests an incentive mechanism to encourage management to act in the interests of stakeholders. Management cannot think like stakeholders if they are not stakeholders. In the previous study conducted by Arieany (2012), the results showed a significant and negative relationship between managerial ownership and companies that experienced financial distress. The first hypothesis is as follows:

\section{H1: Managerial ownership negatively affects financial distress.}

\subsection{Institutional Ownership and Financial Distress}

Institutional ownership is one of the corporate governance mechanisms that can reduce problems in agency theory between owners and managers so that there is an alignment of interests between company owners and managers. Therefore, it does not create a management agency cost that can lead to a company's financial distress. If the institutional ownership is greater, the utilization of company assets will be more efficient. As a result, the potential for financial distress can be minimized. A company with institutional ownership greater than 5 percent indicates its ability to supervise the management (Bodroastuti, 2009). Based on Abdullah's research (2006) in Malaysia, institutional ownership has a significant negative relationship in companies that experience financial distress. The second hypothesis is as follows:

H2: Institutional ownership negatively influences financial distress. 


\subsection{Managerial Agency Cost and Financial Distress}

The company will try to reduce managerial agency costs. Besides external conflicts, there are also internal conflicts within the agents and principals (people tend to be inconsistent). Managerial agency cost is the provision of appropriate incentives to managers and supervise the costs to prevent the desire of managers who may take actions contrary to the objectives of the company's shareholders (Fachrudin, 2011). Research on the effect of managerial agency cost on financial distress by Ayuningtias (2013) and Li et al. (2008) stated that managerial agency cost positively influences the possibility of financial distress. The third hypothesis is as follows:

H3: Managerial agency cost has a positive impact on financial distress.

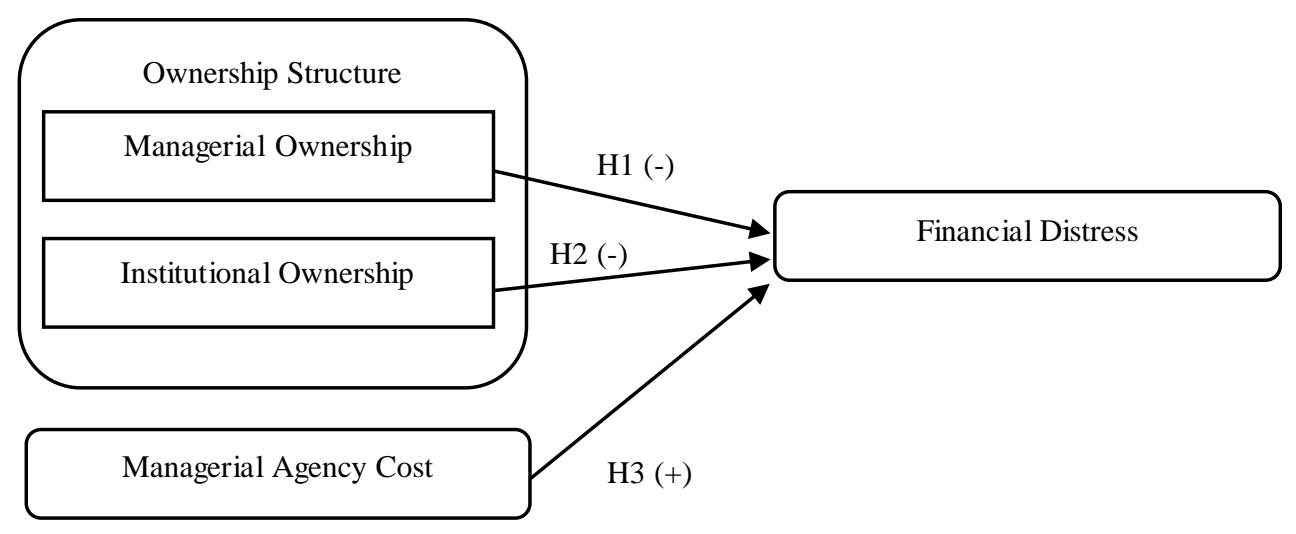

Fig.1. Research Model

\section{Research Method}

The populations in this study were companies listed on the Indonesia Sharia Stock Index year 2016-2018. The sampling method used a purposive sampling method with the following criteria: (1) listed as a company registered since 2016-2018; (2) companies that report financial statements using Rupiah exchange rate; (3) companies that submit complete data related to the research variables; (4) companies that experience financial distress. Based on those criteria, the total sample used in this was 129 companies (43 companies $\mathrm{x} 3$ years). 
Financial distress is measured using an Interest Coverage Ratio (ICR) ratio between earnings before interest tax and interest expense. If the interest coverage ratio shows several more than 1 , it is classified as a company that does not experience financial distress and is given code 1 . Whereas if the interest coverage ratio shows a number less than 1 , then the company can be a company that experiences financial distress and is given the code 0 (Hidayat \& Meiranto, 2014). Managerial ownership is measured using a percentage of share ownership by managers, directors, and commissioners in the company. Institutional ownership is measured through the proportion calculation of company share ownership by institutions of all outstanding shares (Indriastuti, 2012). Managerial agency cost is measured using the administrative cost ratio, which compares administrative costs and sales (Li et al., 2008).

This study was conducted using a logistic regression model because this study has a dependent variable measured using a dummy variable, namely financial distress. Meanwhile, the independent variable is a variable measured by a ratio scale (Ghozali, 2016). The logistic regression equation in this study is formulated as follows:

$$
\mathrm{FD}=\boldsymbol{\beta 0}+\beta 1 \mathrm{X} 1+\beta 2 \mathrm{X} 2+\beta 3 \mathrm{X} 3+\varepsilon
$$

in which:

FD: Financial Distress

$\beta 0$ : Constant

$\beta 1, \beta 2$, and $\beta 3$ : Coefficient

X1: Managerial Ownership

X2: Institutional Ownership

X3: Managerial Agency Cost

\section{Results and Discussion}

\subsection{Descriptive Statistics}

The descriptive statistical calculations result of managerial ownership, institutional ownership, and managerial agency cost are shown in table 1: 
Table 1.

Descriptive Statistic

\begin{tabular}{|c|c|c|c|c|c|}
\hline & $\mathrm{N}$ & Minimum & Maximum & Mean & Std. Deviation \\
\hline Managerial Ownership & 129 & 0.00 & 42.5 & 4.726 & 7.71246 \\
\hline Institutional Ownership & 129 & 14.97 & 98.66 & 68.2522 & 21.33659 \\
\hline Managerial Agency Cost & 129 & 0.00 & 3.65 & 0.2989 & 0.52923 \\
\hline$\overline{\text { Valid N (listwise) }}$ & 129 & & & & \\
\hline
\end{tabular}

Table 1 shows the descriptive statistical data of each variable. The managerial ownership offers an average value of 4.726. It indicates, managerial ownership in Indonesia Sharia Stock Index, which becomes research samples, is not good. Institutional owners hip has an average of 129 samples of 68.2522, which shows that the average Indonesia Sharia Stock Index has institutional ownership for 68\% during 20162018. Managerial agency cost exposes an average value of 0.2989 which means that managerial agency cost in Indonesia Sharia Stock Index used as research samples is relatively low.

\subsection{Wald Test Result}

The results of hypothesis testing in this research used the logistic regression test model. It is used to test the effect of managerial ownership, institutional ownership, and managerial agency costs in predicting the possibilities for financial distress in a company.

Table 2 shows the Chi-square value of 6.758 with a significance of 0.788 . Based on these results, because the significance value is greater than 0.05 , it can be concluded that the model can predict the value of the observation. The magnitude of the determination coefficient in the logistic regression model is shown by Nagelkerke's $R$ Square value of 0.186 . The independent variable is explained by the independent variable at $18.6 \%$, while other variables outside the research model explain the remaining $81.4 \%$. The hypothesis test results show that (1) managerial ownership has a Wald value of 1.987 with a significance level of 0.459 . Since the significance level 
above $5 \%$ and the value of coefficient $\mathrm{b}$ are negative, it can be said that managerial ownership does not have any effect on the prediction of financial distress in a company. This result shows that in the logistic regression model the hypothesis 1 is not supported.

Table 2.

Wald Test Result

\begin{tabular}{llllllll}
\hline $\begin{array}{c}\text { Dependent } \\
\text { Variable }\end{array}$ & Independent Variable & B & SE. & Wald & df & Sig & $\begin{array}{c}\text { Exp } \\
\text { (B) }\end{array}$ \\
\hline \multirow{4}{*}{ Financial Distress } & Managerial Ownership & -1.954 & 2.119 & 1.987 & 1 & .459 & 1.490 \\
\cline { 2 - 7 } & Institutional & -5.139 & 2.461 & 9.118 & 1 & .013 & 1.129 \\
& Ownership & & & & & & \\
\cline { 2 - 8 } & Managerial Agency & -1.291 & 2.983 & 1.120 & 1 & .952 & 1.939 \\
& Cost & & & & & & \\
\hline Chi-square & 6.758 & & & & & & \\
\hline Nagelkerke R &, 186 & & & & & \\
Square & & & & & & & \\
\hline
\end{tabular}

Institutional ownership has a Wald value of 9,118 with a significance level of 0.013. Since the significance level, fewer than $5 \%$, and the value of coefficient $b$ is negative. It can be said that institutional ownership has a negative effect on the prediction of financial distress in a company. This result shows that in the logistic regression model, hypothesis 2 is accepted. Managerial agency cost has a Wald value of 1.120 with a significance level of 0.952 . Since the significance level above $5 \%$ and the value of coefficient $b$ are negative, it can be said that the managerial agency cost has not had any effect on the prediction of financial distress in a company. This result shows that in the logistic regression model, hypothesis 3 is not supported.

\subsection{Discussion}

\subsubsection{Managerial Ownership and Financial Distress}

Managerial ownership does not have any effect on the prediction of financial distress. It signifies that company managers' size of share ownership does not affect the 
prediction of financial distress. It is due to many companies that do not apply the policy to own company shares for its management. This study cannot support agency theory, which explains that managerial ownership can reduce agency costs because of the alignment of interests between agents and principals.

Managers will tend to use resources excessively when the agency costs of the company are large. If it occurs on an ongoing basis, it will cause the company's finances to decline. As a result, the occurrence of financial distress increases. The practical implication of the study is that companies incorporated in the Indonesia Sharia Stock Index do not have to pay attention to the high managerial ownership in a company because high managerial ownership cannot reduce the company's financial difficulties. It is because not all companies have managerial ownership. The company can make efforts to apply a policy to the management to own shares in the company. The results of this study are in line with research conducted by Ayuningtias (2013); Xiaolan \& Zongjun (2006) that managerial ownership variables do not affect financial distress.

\subsubsection{Institutional Ownership and Financial Distress}

Institutional ownership has a negative effect on the prediction of financial distress. The greater ownership of institutions will encourage a more optimal level of management performance supervision. It is because institutional ownership represents a source of power that can support the existence of management. With the increasing supervision, institutional investors can help in reducing agency costs incurred by companies so that the possibility of losses to companies that result in financial distress will be smaller Ayuningtias (, 2013). Companies with sizeable institutional ownership (more than 5\%) indicate their ability to influence management policies through voting.

This study supports agency theory because, through this institutional ownership, the winner of institutional shares can replace or strengthen the monitoring function in a company to reduce the possibility of the company experiencing financial distress (Laurenzia and Sufiyati, 2015). The results of this research are consistent with research conducted by Arieany (2012), Ayuningtias (2013), Laurenzia, and Sufiyati (2015) that institutional ownership has a negative effect on financial distress. 


\subsubsection{Managerial Agency Cost and Financial Distress}

Managerial agency cost has no effect on the prediction of financial distress. The high and low managerial agency costs in companies listed on the Indonesia Sharia Stock Index cannot predict financial distress. This result is because the administrative costs component used in this research does not only cover managerial costs such as managerial salary costs, executive fees, travel costs, entertainment costs, conference expenses, and welfare payments (Li et al., 2008). Instead, it also includes electricity costs, depreciation, building rent, and other administrative costs not included in managerial costs. Therefore, this causes a large administrative costs ratio (Ayuningtias., 2013).

It confirms that the size of the managerial agency costs contained in the company does not affect the possibility of financial distress. The results of this study do not support the agency theory. The emergence of managerial agency costs is due to the separation of functions from the principal and the agent who carries out the task and behaves as if he maximizes the principal's welfare. It results in actions from agents who take advantage of agency costs to fulfill their interests.

The results of this research are different from the research conducted by Li et al. (2008) and Ayuningtias (2013). They suggested that the managerial agency costs proxied by administrative cost ratios positively impact financial distress. This situation is because administrative costs incurred as managerial agency costs can adversely affect the company's financial condition.

\section{Conclusions, Implications, and Limitation}

Managerial ownership and managerial agency costs do not affect financial distress predictions in companies listed on the Indonesia Sharia Stock Index. On the other hand, institutional ownership has a negative effect on the prediction of financial distress. This study has contributed to our theoretical understanding of corporate governance, especially related to the ownership structure and managerial agency costs that can predict financial distress. For companies as the Indonesia Islamic stock 
index members, it can guide implementing good corporate governance to manage managerial agency costs for minimizing financial distress. For investors, it can be used as a reference in making investment decisions. The limitation of this research is the low ability of independent variables in explaining the dependent variable, which is only $18.6 \%$. Therefore, it would be better for future research to add other independent variables such as financial ratios, audit committees, and company size and extend the research time.

\section{Reference}

Abdullah, S. N. (2006). Board Structure and Ownership in Malaysia: The Case of Distressed listed Companies. Corporate Governance, 6(5), 582-594.

Agus, S. (2011). Manajemen Keuangan Teori dan Aplikasi. Yogyakarta: BPFE.

Al-Khatib, H. B. \& A. A.-H. (2012). Predicting Financial Distress of Public Companies Listed in Amman Stock Exchange. European Scientific Journal, 8(15)

Arieany Widya Deviacita. (2012). Analysis of the Effect of Corporate Governance Mechanisms on Financial Distress. Diponegoro Journal of Accounting., 1(1), 13.

Arief Moh. Effendi. (2009). The Power of Good Corporate Governance: Theory and Implementation. Jakarta: Salemba Empat.

Ayuningtias. (2013). Analysis of the Effect of Ownership Structure, Board Composition, and Agency Cost Against Financial Distress. Jurnal Ilmu Manajemen, 1(1).

Azwar, I. (2015). Financial Distress Prediction Model with Binary Logit (Case Study in JII). Jurnal BPPK, 8(1), 21-40.

Bhunia, A. S. I. U. K. \& S. M. (2011). Prediction of Financial Distress: A Case Study of Indian Companies. Asian Journal of Business Management, 3(3), 210-218.

Bodroastuti, T. R. I. (2009). Effect of Corporate Governance Structure on Financial Distress. Jurnal STIE Widya Manggala, 1-15.

Brigham, E.F. \& Daves, P. R. (2003). Intermediate Financial Management with Thomson One. United States of America: Cengage South-Western.

Classens, Stijn. Simeon Djankov, and L. K. (1999). Resolution of Corporate Distress in East Asia. World Bank Policy Research Working Paper. 
Elloumi, F., Gueyié, J.-P., \& Gueyie, J. (2001). Financial Distress and Corporate Governance: An Empirical Analysis. Corporate Governance, 15-23.

Emrinaldi Nur, D. . (2007). Analysis of the Effect of Corporate Governance Practices on Corporate Financial distress (Financial Distress: An Empirical Study). Jurnal Bisnis Dan Akuntansi, 9(1), $84-108$.

Fachrudin Khaira Amalia. (2011). Analysis of the Effect of Capital Structure, Company Size, and Agency Cost on Company Performance. Jurnal Akuntansi Dan Keuangan, 13(1), $37-46$.

Ghozali, Imam. (2016). Multivariate Analysis Application with SPSS Programme (V). Semarang: Universitas Diponegoro.

Haddad, A., Jamil, F., \& Sufy, A. (2011). The Effect of Corporate Governance on the Performance of Jordanian Industrial Companies: An empirical study on Amman Stock Exchange. International Journal of Humanities and Social Science, 1(4), 55-69.

Hanifah, Oktita Earning \& Purwanto, A. (2013). The Effect of Corporate Governance Structure and Financial Indicators on Financial Distress Conditions. Diponegoro Journal of Accounting, 2(2).

Hidayat, M. A., \& Meiranto, W. (2014). Financial Distress Prediction of Manufacturing Companies in Indonesia. Diponegoro Journal of Accounting, 3, 1-11.

Indriastuti, Maya \& Ifada, Luluk. Muhimatul. (2011). The Influence of the Quality of the Implementation of Corporate Governance and the Complexity of Banks against Fraud (Case Study at Commercial Banks in 2010). Jurnal Ekonomi \& Bisnis, 12(2), 168178

Indriastuti, Maya. (2012). Analysis of Auditor Quality and Corporate Governance on Earnings Management. Eksistansi, 4(2).

Jensen, Michael and Meckling, W. (1976). Theory of the Firm: Managerial Behavior, Agency Cost, and Ownership Structure. Journal O F Financial Economics, 3, 305-360.

Laurenzia, C. \& Sufiyati. (2015). Effects of Institutional Ownership, Board of Commissioners Size, Liquidity, Activities and Leverage on Financial Distress of Manufacturing Companies Listed on the Indonesia Stock Exchange. Jurnal Ekonomi, 20(1), 72-88.

Li, H., Wang, Z., \& Deng, X. (2008). Ownership, Independent Directors, Agency Costs and Financial Distress: Evidence from Chinese Listed Companies. Corporate Governance, 8(5), 622-636.

Miglani, S., K. Ahmed and Henry, D. (2014). Voluntary Corporate Governance Structures and Financial Distress: Evidence from Australia'. Journal of Contemporary Accounting and Economics, 11(1), 18-30. 
The Indonesian Journal of Accounting Research - May, Vol. 24, No.2, 2021

Muranda, Z. (2006). Financial Distress and Corporate Governance in Zimbabwean Banks. Managerial Finance, 6(5).

Parulian, S. R. (2007). Relationship of Ownership Structure, Independent Commissioners and Financial Distress Conditions of Public Companies. Jurnal Akuntansi Dan Keuangan, $1(3)$.

Platt, H., \& Platt, M. B. (2002). Predicting Financial Distress. Journal of Financial Service Professionals, 56, 12-15.

Porter E Michel. (1999). Towards a Dynamic Theory of Strategy. Strategic Management Journal, 12, 95-117.

Sutedi Adrian. (2011). Good Corporate Governance. Jakarta: Sinar Grafika.

Triwahyuningtias, M. \& Muharam, H. (2012). Analysis of the Effect of Ownership Structure, Board Size, Independent Commissioners, Liquidity, and Leverage on the Occurrence of Financial Distress (Study of Manufacturing Companies Listed on the Indonesia Stock Exchange in 2008-2010). Diponegoro Journal of Management, 1(1), 1-14.

Wruck, K. (1990). Financial Distress, Reorganization, and Organizational Efficiency. Journal of Financial Economics, 27, 419-444

Xiaolan, Deng \& Zongjun, W. (2006). Ownership Structure and Financial Distress: Evidence from Public-Listed Companies in China. International Journal of Management. 